JPPUMA: Jurnal Ilmu Pemerintahan dan Sosial Politik UMA (Journal of Governance and Political Social UMA),

7 (2) (2019): 227-235, DOI: http://dx.doi.org/10.31289/ippuma.v7i2.3015

JPPUMA: Jurnal Ilmu Pemerintahan dan Sosial Politik UMA

(Journal of Governance and Political Social UMA)

Available online http://ojs.uma.ac.id/index.php/jppuma

\title{
Partisipasi Politik Masyarakat Kecamatan Medan Maimun pada Pemilihan Gubernur Sumatera Utara Tahun 2018
}

\section{Political Participation Medan Maimun District Community at Election Governor North Sumatra Year 2018}

\author{
Faiz Albar Nasution* \& Kushandajani \\ Program Studi Magister Ilmu Politik, Fakultas Ilmu Sosial dan Ilmu Politik, \\ Universitas Diponegoro, Indonesia
}

Diterima: 25 Oktober 2019; Disetujui 29 November 2019; Dipublish 1 Desember 2019

\begin{abstract}
Abstrak
Partisipasi masyarakat dalam menggunakan hak pilih menjadi indikator terpenting dari keberhasilan penyelenggaraan Pilkada. Namun, masyarakat Kecamatan Medan Maimun memiliki partisipasi terendah dari 21 Kecamatan Kota Medan pada Pilgub Sumut 2018. Kondisi ini menggambarkan euforia Pilkada ternyata tidak diikuti oleh jumlah pengguna hak pilih. Penelitian ini bertujuan untuk menganalisis partisipasi politik masyarakat Kecamatan Medan Maimun pada Pilgub Sumut 2018. Dalam penelitian ini metode yang digunakan yaitu kualitatif deskriptif. Teknik pengumpulan data dengan cara dokumentasi dan wawancara mendalam, dilakukan kepada informan yang berasal dari lembaga penyelenggara Pemilu, politik, sosial dan masyarakat Kecamatan Medan Maimun. Analisa data menggunakan teknik Miles dan Huberman antara lain: reduksi data, display data dan menarik kesimpulan. Hasil penelitian menunjukkan pertama, hierarki partisipasi politik masyarakat Kec. Medan Maimun didominasi partisipasi dalam pemberian suara dan apathy total. Kedua, faktor - faktor yang mempengaruhi partisipasi masyarakat pada Pilgub Sumut 2018 yaitu: kesadaran politik, kepercayaan terhadap pemerintah, status sosial dan status ekonomi, afiliasi politik orang tua dan pengalaman berorganisasi.
\end{abstract}

Kata kunci: Partisipasi Politik, Pemilihan Kepala Daerah

Abstract

Community participation in the use of voting rights becomes the most important indicator of the success regional elections. However, the community of Medan Maimun subdistrict has the lowest participation from 21 Medan City subdistrict at Pilgub Sumut 2018. This condition illustrates that euphoria of the regional election was not followed by number of users of voting rights. This research aims to analyze political participation community of Medan Maimun subdistrict at Pilgub Sumut 2018. In this study the method used is qualitative descriptive. The technique data collection by of documentation and in-depth interviews, conducted to informant that originated from the Institute of election, political, social and community District Medan Maimun. Data analysis using Miles and Huberman techniques are: data reduction, data display and draw conclusions. Results showed first, the hierarchy political participation in Medan Maimun subdistrict dominated by participation in voting and total apathy. Secondly, factors influencing community participation in Pilgub Sumut 2018 are: Political consciousness, trust in government, social status and economic status, political affiliation of parents and organizational experience.

Keywords: political participation, regional elections

How to Cite: Nasution, A.F. Kushandajani. (2019). Partisipasi Politik Masyarakat Kecamatan Medan Maimun Pada Pemilihan Gubernur Sumatera Utara Tahun 2018. JPPUMA: Jurnal Ilmu Pemerintahan dan Sosial Politik UMA (Journal of Governance and Political Social UMA), 7 (2): 227-235.

${ }^{*}$ Corresponding author:

E-mail: Faiznasution92@gmail.com

ISSN 2549-1660 (Print)

ISSN 2550-1305 (Online) 


\section{PENDAHULUAN}

Pemilihan umum adalah salah satu pilar utama dari sebuah negara demokrasi, karena pemilu dapat merepresentasikan kedaulatan rakyat (Hendrik, 2010). Sejak diterbitkan UU Nomor 10 Tahun 2016 pemerintah pusat menjadikan Pilkada sebagai instrumen penting dalam penyelenggaraan Pemerintahan Daerah yang demokratis. Hal ini menunjukkan bahwa rakyat sebagai pemegang kedaulatan dalam menentukan kebijakan daerah. Kegiatan ini dapat dilihat pada Pilkada serentak tahun 2018, diikuti 17 Provinsi dan 115 kabupaten dan 39 Kota, yang salah satunya Kota Medan ikut melaksanakan Pilgub Sumut.

Pada pelaksanaan Pilgub Sumut 2018 partisipasi masyarakat Kota Medan dalam menggunakan hak pilih meningkat, jika dibandingkan dengan Pilkada sebelumnya. Namun, rekapitulasi hasil perolehan suara Pilgub Sumut 2018 menunjukkan partisipasi politik Kota Medan dinilai masih rendah, hal ini di sebabkan karena tidak tercapainya target KPU Kota Medan untuk meningkatkan partisipasi sebesar 78\% (Simarmata, 2018). Berikut data partisipasi masyarakat pada setiap Pilkada di Kota Medan :

Tabel 1.1. Data Partisipasi Masyarakat Kota Medan pada Pilkada

$\begin{array}{llll}\text { Pilkada } & \text { Tahun } & \begin{array}{l}\text { Jumlah } \\ \text { Pemilih }\end{array} & \begin{array}{l}\text { Tingkat } \\ \text { Partisipasi }\end{array} \\ \text { Walikota } & 2005 & 1.450 .596 & 54,70 \% \\ \text { Gubernur } & 2008 & 1.725 .045 & 47,10 \% \\ \text { Walikota } & 2010 & 1.961 .723 & 38,28 \% \\ \text { Gubernur } & 2013 & 2.123 .878 & 36,58 \% \\ \text { Walikota } & 2015 & 1.998 .835 & 25,38 \% \\ \text { Gubernur } & 2018 & 1.641 .648 & 55,80 \%\end{array}$

Sumber: KPUD Kota Medan.

Tabel 1.1. memperlihatkan terjadinya pasang surut partisipasi masyarakat Kota Medan dalam menggunakan hak pilih pada setiap Pilkada. Kondisi tersebut dapat dirasakan sejak Pilkada Kota Medan dilaksanakan dari tahun 2005 sampai
2018. Rendahnya tingkat partisipasi masyarakat Kota Medan pada Pilgub Sumut 2018 sebesar 55,80\%, juga dapat dilihat pada Pilwal Medan 2015, dengan tingkat partsipasi 25,38\%. Kondisi ini menggambarkan euforia Pilkada di Kota Medan ternyata tidak diikuti oleh jumlah pengguna hak pilih. sehingga tahapan tahapan Pilkada dinilai tidak mampu meningkatkan kesadaran masyarakat untuk ikut memilih pada Pilgub Sumut 2018. Berikut hasil rekapitulasi perolehan suara Pilkada 2015 dan Pilkada 2018 di setiap Kecamatan Kota Medan:

Tabel 1.2. Rekapitulasi Hasil Perolehan Suara Pilgub Sumut 2018 dan Pilwal 2015 di Kota Medan.

\begin{tabular}{|c|c|c|c|}
\hline \multirow[b]{2}{*}{ No } & \multirow[b]{2}{*}{ Kecamatan } & \multicolumn{2}{|c|}{ Tingkat Partisipasi } \\
\hline & & $\begin{array}{l}\text { Pilkada } \\
2015\end{array}$ & $\begin{array}{l}\text { Pilkad } \\
\text { a } 2018\end{array}$ \\
\hline 1 & $\begin{array}{l}\text { Medan } \\
\text { Tuntungan }\end{array}$ & $27,4 \%$ & $60,3 \%$ \\
\hline 2 & Medan Johor & $26,8 \%$ & $56,6 \%$ \\
\hline 3 & Medan Amplas & $21,6 \%$ & $61,4 \%$ \\
\hline 4 & Medan Denai & $24,0 \%$ & $57,8 \%$ \\
\hline 5 & Medan Area & $31,2 \%$ & $61,2 \%$ \\
\hline 6 & Medan Kota & $27,4 \%$ & $56,4 \%$ \\
\hline 7 & $\begin{array}{l}\text { Medan } \\
\text { Maimun }\end{array}$ & $27,1 \%$ & $48,1 \%$ \\
\hline 8 & Medan Polonia & $24,5 \%$ & $57,4 \%$ \\
\hline 9 & Medan Baru & $22,3 \%$ & $53,5 \%$ \\
\hline 10 & Medan Selayang & $29,1 \%$ & $60,3 \%$ \\
\hline 11 & Medan Sunggal & $23,2 \%$ & $54,4 \%$ \\
\hline 12 & Medan Helvetia & $23,2 \%$ & $61,8 \%$ \\
\hline 13 & Medan Petisah & $25,4 \%$ & $56,3 \%$ \\
\hline 14 & Medan Barat & $30,4 \%$ & $55,2 \%$ \\
\hline 15 & Medan Timur & $34,6 \%$ & $62,1 \%$ \\
\hline 16 & $\begin{array}{l}\text { Medan } \\
\text { Perjuangan }\end{array}$ & $25,8 \%$ & $60,8 \%$ \\
\hline 17 & $\begin{array}{l}\text { Medan } \\
\text { Tembung }\end{array}$ & $26,3 \%$ & $57,8 \%$ \\
\hline 18 & Medan Deli & $25,9 \%$ & $55,3 \%$ \\
\hline 19 & Medan Labuhan & $30,6 \%$ & $59,4 \%$ \\
\hline 20 & Medan Marelan & $30,7 \%$ & $65,0 \%$ \\
\hline 21 & Medan Belawan & $28,5 \%$ & $54,7 \%$ \\
\hline
\end{tabular}

Sumber: Data di olah dari KPUD Kota Medan

Hasil rekapitulasi perolehan suara Pilgub Sumut 2018 di Kota Medan menunjukkan Kec. Medan Maimun menempati partisipasi terendah dari 21 Kecamatan, dengan tingkat partisipasi sebesar 48,1\%. Namun, jika membandingkan kedua data Pilwal Medan 2015 dan Pilgub Sumut 2018, ada sesuatu 
yang menarik, yaitu keikutsertaan masyarakat Kec. Medan Maimun dalam kontestasi Pilkada selalu mendapatkan angka partisipasi yang rendah. Asumsi ini didasarkan dari kedua data yang disajikan, seperti Kec. Medan Amplas pada Pilkada 2015 partisipasi $21,6 \%$ dan pada Pilkada 2018 partisipasi naik signifikan menjadi 61,4\%. Selanjutnya, Kec. Medan baru Pilkada 2015 partisipasi sebesar 22,3\% dan di Pilkada 2018 partisipasi naik menjadi 53,5\%. Sedangkan tingkat partisipasi masyarakat Kec. Medan Maimun pada Pilkada 2015 partisipasi 27,1\% dan pada Pilkada 2018 tidak mengalami peningkatan yang cukup tinggi dengan tingkat partisipasi sebesar 48,1\%.

Fenomena rendahnya partisipasi masyarakat Kec. Medan Maimun pada Pilgub Sumut 2018 mendapatkan perhatian KPUD Kota Medan yang menjadikan Kec. Medan Maimun sebagai prioritas untuk diberikan pendidikan dan sosialisasi politik dalam meningkatkan partisipasi pemilih di Kota Medan (Siregar, 2019). Data ini menjelaskan partisipasi masyarakat Kec. Medan Maimun menjadi salah satu indikator terpenting dari keberhasilan Pilkada di Kota Medan. Namun, rendahnya partisipasi masyarakat Kec. Medan Maimun dalam menggunakan hak pilih pada setiap Pilkada menggambarkan buruknya kualitas demokrasi di Kota Medan. Maka partisipasi politik di Kec. Medan Maimun menarik untuk diteliti, karena Kec. Medan Maimun berlokasi dekat pusat Kota Medan dan memiliki tingkat keragaman yang tinggi mulai dari komposisi persebaran penduduk, agama, maupun dari persebaran etnis.

Penelitian terdahulu, telah banyak melakukan analisis terhadap masalah partisipasi politik masyarakat pada Pilkada. Akan tetapi persoalan tentang partisipasi politik sampai saat ini masih menjadi masalah yang belum dapat diselesaikan. Hal tersebut juga merupakan salah satu ciri ilmu sosial yang sangat dinamis dan terus berkembang.

Adapun beberapa penelitian terdahulu yang dapat dijadikan rujukan dalam penelitian ini. Marlini Tarigan berjudul "Partisipasi Politik Masyarakat Kab. Temanggung Dalam Pelaksanaan Pilkada Tahun 2008" (Tarigan, 2009). Rio Sholihin berjudul "Partisipasi Politik Masyarakat dalam Pilgub Kaltim 2013-2018 di Kec. Sungai Pinang Kota Samarinda" (Sholihin, 2014). Yustinus Usfinit, dkk yang berjudul "Perspektif Partisipasi Politik Masyarakat Pada Pilkada Kota Malang” (Usfinit, dkk, 2014). Pertama Yul Asmara Pane berjudul "Partisipasi Politik Masyarakat Dalam Pilkada Sumut Tahun 2013 di Kota Padangsidimpuan" (Asmara Pane, 2015). Sri Suharianti melakukan penelitian berjudul "Analisis Partisipasi Politik Masyarakat Pada Pilkada langsung Di Kabupaten Barito Selatan Tahun 2017 (Suhartini, 2018). Heri Kusmanto. Meneliti "Peran Badan Permusyawaratan Daerah dalam Meningkatkan Partisipasi Politik Masyarakat", (Kusmanto, 2013). Penelitian Agung Suharyanto tentang "Partisipasi Politik Masyarakat Tionghoa dalam Pemilihan Kepala Daerah" (Suharyanto, 2014). Julia Ivanna, dkk, tentang "Peran Media Cetak dalam Meningkatkan Partisipasi Politik di Kelurahan Bandar Selamat Kecamatan Medan Tembung Kota Medan" (Ivanna, Pardede \& Iqbal, 2018). Penelitian Zega dkk, tentang "Pengaruh Program Rumah Pintar Pemilu terhadap Partisipasi Politik Masyarakat pada Kantor Komisi Pemilihan Umum Kota Medan, (Zega. Muda, Batubara \& Suharyanto, 2018). Penelitian Hasibuan dkk, tentang "Strategi Komisi Pemilihan Umum Provinsi Sumatera Utara dalam Meningkatkan Partisipasi Masyarakat Pada Pemilihan Gubernur Sumatera Utara 2018 (Hasibuan, Kadir \& Nasution, 2018). Penelitian Agung Suharyanto, tentang "Surat Kabar sebagai Salah Satu Media Penyampaian Informasi Politik pada Partisipasi Politik Masyarakat (Suharyanto, 2016), 
Penelitian dalam artikel ini pada dasarnya mengambil posisi yang berbeda dalam beberapa hal dengan penelitianpenelitian sebelumnya dimana penelitian ini menekankan "Analisis Partisipasi Politik Masyarakat Kecamatan Medan Maimun Pada Pilgub Sumut 2018". Penelitian ini diharapkan bisa memberikan kontribusi kepada penelitian terdahulu karena penelitian ini mempunyai kelebihan. Hal tersebut dapat dilihat dari data partisipasi politik masyarakat dalam menggunakan hak pilih pada Pilkada di Kota Medan yang sudah dilaksanakan seperti studi kasus di Kec. Medan Maimun menunjukkan partisipasi masyarakat selalu menjadi terendah pada Pilkada 2015 dan Pilkada 2018 di Kota Medan. Masalah ini perlu untuk diteliti agar memberikan gambaran sebagai berikut: (1) Bagaimana partisipasi masyarakat Kec. Medan Maimun pada Pilgub Sumut tahun 2018, (2) Faktor - faktor apa saja yang mempengaruhi rendahnya partisipasi politik masyarakat di Kec. Medan Maimun pada Pilgub Sumut tahun 2018. Mengenai tujuan dalam penelitian untuk: (1) Menganalisis partisipasi politik masyarakat Kecamatan Medan Maimun pada Pilgub Sumut Tahun 2018.

\section{METODE PENELITIAN}

Metode penelitian ini menggunakan deskriptif dengan pendekatan kualitatif. Penelitian deskriptif dapat diartikan sebagai prosedur pemecahan masalah yang diselidiki melalui gambaran atau melukiskan keadaan subjek atau objek terhadap fenomena sosial berdasarkan gejala - gejalanya (Nawawi, 2019).

Fokus penelitian ini adalah pada analisis partisipasi masyarakat Kecamatan Medan Maimun dalam Pilgub Sumut tahun 2018. Lokus penelitian terdapat pada Kecamatan Medan Maimun yang terdiri dari enam kelurahan yaitu: Aur, Hamdan, Jati, Kampung baru, Sei mati dan Suka raja. Penelitian ini mengunakan teknik analisis data kulitatif model Miles dan Huberman.
Aktivitas dalam analisis data kuliatif tersebut meliputi: reduksi data, display data, dan penarikan kesimpulan (Miles \& Huberman, 2007).

\section{HASIL DAN PEMBAHASAN}

Pada penyelenggaraan Pilgub Sumut 2018 di Kota Medan, masyarakat Kec. Medan Maimun memiliki jumlah pemilih 43.193 jiwa, pengguna hak pilih 20.786 jiwa dan tidak menggunakan hak pilih 22.407 jiwa. Hasil perhitungan suara menunjukkan partisipasi masyarakat Kec. Medan Maimun sebesar 48,12\%, menjadikan partisipasi terendah dari 21 Kecamatan di Kota Medan. Maka hierarki partisipasi politik masyarakat Kec. Medan Maimun perlu ditelaah, agar nantinya mampu memberikan gambaran alternatif bagi KPU dan Partai Politik dalam meningkatkan partisipasi pemilih di Kota Medan.

Michael Rush dan Phillip Althoff menjelaskan hierarki partisipasi politik sebagai berikut (Rush, 2011): (1) Menduduki dan mencari jabatan politik atau administratif. (2) Menjadi anggota aktif/pasif suatu organisasi politik. (3) Keanggotaan aktif/pasif suatu organisasi semu politik. (4) Partisipasi dalam rapat umum, demontrasi dan sebagainya. (5) Partisipasi dalam diskusi politik informal minat umum dalam politik. (6) Partisipasi dalam pemberian suara (voting). (7) Apathi total.

Urutan di atas memperlihatkan masyarakat yang memiliki tingkat partisipasi yang paling tinggi di miliki seseorang yang menduduki dan mencari jabatan politik/administratif. Sedangkan hierarki terendah dalam partisipasi politik adalah orang yang apatis secara total. Urutan ini menunjukkan semakin tinggi hierarki partisipasi politik maka semakin kecil kuantitas dari keterlibatan partisipasi masyarakat. Namun, partisipasi Politik masyarakat Kec. Medan Maimun pada Pilgub Sumut 2018 didominasi partisipasi dalam pemberian suara dan apatis. Pendapat ini senada dengan Komisioner 
KPU Kota Medan, Edy Suhartono menyatakan bahwa: "Saat ini Kecamatan di Kota Medan yang belum keluar zona rawan partisipasi yaitu di Kec. Medan Maimun 48,12\%, sehingga menjadi tingkat partisipasi terendah dalam Pilgubsu 2018. Tingkat partisipasi masyarakat Kec. Medan Maimun terbagi dalam 2 kategori; rasional dan emosional. Pertama, Rasional seseorang dalam menggunakan hak pilih berdasarkan patronase yang jelas dan sifatnya spontan dan sesaat. Contoh kalau ustad menganjurkan memilih salah satu calon, pasti mereka juga memilih, dan berlaku dalam basis agama dan kultural. Kedua, emosional seseorang mengakibatkan pragmatisme, dalam memilih salah satu calon. Hal ini diakibatkan seseorang menilai tidak ada bermanfaatnya kepada dirinya secara langsung dan ini di alami seseorang yang berpendidikan rendah dan berpendidikan tinggi".

Partisipasi masyarakat Kec. Medan Maimun pada Pilgub Sumut 2018 jika dilihat dengan teori hierarki partisipasi poltik Michael Rush dan Phillip Althoff masuk kedalam kategori; partisipasi dalam pemberian suara dan apathi total. Masyarakat berpartisipasi dalam pemberian suara berdasarkan patronase terhadap suatu keyakinan berbasis agama atau kultur dan partisipasi ini hanya partisipasi politik aktif yang sangat kecil. Partisipasi tersebut dipengaruhi isu identitas terhadap salah satu Pasalon, isu identitas seperti: Putra daerah dan Islam sangat mempengaruhi masyarakat Kec. Medan Maimun dalam menggunakan hak pilih pada Pilgub sumut 2018.

Khusus masyarakat Kec. Medan Maimun apathi total diakibatkan sifat emosional seseorang yang cenderung paragmatisme. Hal ini dipengaruhi kepala daerah sebelumnya tidak melakukan perubahan yang dirasakannya secara langsung dan Pasalon Pilgub Sumut 2018 memiliki reputasi buruk. sehingga kurangnya kepercayaan terhadap pemerintah dan calon mempengaruhi masyarakat Kec. Medan Maimun untuk tidak menggunakan hak pilih pada Pilgub Sumut 2018 di Kota Medan.

Partisipasi masyarakat Kec. Medan Maimun yang didominasi partisipasi dalam pemberian suara dan apathi total tentu banyak dipengaruhi beberapa faktor. Dalam penjelasan faktor tinggi rendahnya partisipasi politik tulisan ini merujuk pada Ramlan Surbakti dengan membagi lima faktor yang dianggap mempengaruhi tinggi rendahnya partisipasi politik, sebagai berikut (Surbakti, 2010) : (1) Kesadaran Politik. (2) Kepercayaan Terhadap pemerintah. (3) Status Sosial dan Status Ekonomi. (4) Afiliasi Politik Orangtua. (5) Pengalaman Organisasi.

Teori ini menjelaskan bahwa seseorang memiliki kesadaran politik dan kepercayaan terhadap pemerintah yang tinggi, partisipasi politik cenderung aktif, sebaliknya, kesadaran politik dan kepercayaan terhadap pemerintah rendah, partisipasi politik cenderung pasif. Kedua faktor tersebut tidak berdiri sendiri, melainkan juga dipengaruhi oleh faktor status sosial dan ekonomi, afiliasi politik orangtua dan pengalaman berorganisasi

Kesadaran politik dapat dilihat dari pengetahuan seseorang terhadap hak dan kewajiban sebagai warga negara terhadap kegiatan politik. Namun, kesadaran politik masyarakat Kec. Medan Maimun menjadikan hak dan kewajiban dalam Pilkada hanya sebatas pemahaman saja tanpa dibarengi pelaksanaan kegiatan menggunakan hak pilih, mengontrol jalannya Pilkada, dan mengontrol program yang ditawarkan calon, hal ini dipengaruhi kurangnya kepercayaan terhadap pemerintah. Sehingga sebagian masyarakat masih dipengaruhi faktor untung rugi yang cenderung money politic. Pendapat tersebut dapat dibuktikan dengan pernyataan Bpk Guntur sebagai Ketua Karang Taruna kec. Medan Maimun menyatakan: "Kesadaran masyarakat Medan Maimun dalam memilih masih 
minim. Masalah ini dipengaruhi money politic, masyarakat enggan datang ke TPS jika tidak ada duit, faktor ini di akibatkan masyarakat sudah kesal, karena siapa saja yang menjadi pemimpin, masalah Kota Medan tidak kunjung selesai".

Faktor selanjutnya, melihat teritorial Kec. Medan Maimun dekat dengan pusat Kota menjadi tempat lingkungan para pelaku usaha, sehingga menimbulkan masalah status kependudukan. Kurangnya kesadaran masyarakat asli dan pendatang untuk mengurus surat keterangan domisili tempat tinggal, mengakibatkan saat pemilihan masyarakat tidak menggunakan hak pilih dikarenakan lokasi TPS tidak sesuai dengan tempat tinggalnya. Pendapat serupa dikatakan Bpk Ridwan sebagai tokoh masyarakat Kec. Medan Maimun yang mengatakan: "Sebagian masyarakat masih rendah kesadarannya untuk menggunakan hak pilihnya dan malas mengurus surat keterangan tempat tinggal, dapat dilihat Kec. Maimun banyak masyarakat yang secara administrasi berdomisili disini tetapi tidak tinggal disini, sehingga pada saat pemilihan mereka tidak menggunkan hak pilih".

Rendahnya kesadaran masyarakat dalam menggunakan hak pilih dan mengurus status kependudukan menjadi salah satu penyebab rendahnya partisipasi masyarakat Kec. Medan Maimun pada Pilgub Sumut 2018.

Faktor kepercayaan terhadap pemerintah sangat menentukan partisipasi masyarakat untuk menggunakan hak pilihnya pada Pilgub Sumut 2018. Penilaian masyarakat terhadap kinerja pemerintah dari pembuatan kebijakan dan pelaksanaan program yang dijanjikan, akan memberikan kepercayaan terhadap calon kepala daerah untuk diberi amanah. Namun, sampai saat ini masyarakat Kec. Medan Maimun masih sulit untuk memberikan penilain positif terhadap Pemko Medan yang dinilai gagal memperbaiki masalah Kota Medan. Asumsi tersebut didukung pernyataan Bpk. Dr.
Takari selaku Sekretaris MABMI Sumut mengatakan: "Masyarakat sudah hilang kepercayaannya, karena dari eksekutif dan legislatif selalu terjerat kasus korupsi, masalah ini diakibatkan tidak jalannya kaderisasi di Partai politik, sehingga masyarakat menilai siapapun yang nantinya menjadi pemimpin tidak akan melakukan perubahan yang siginifikan di Kota Medan".

Rendahnya kepercayaan terhadap pemerintah dan calon meliputi penilaian masyarakat terhadap rekam jejak calon, visi - misi, calon dapat dipengaruhi dalam perumusan kebijakan. Pendapat senada dengan pernyataan Bpk. Alimin sebagai Tokoh masyarakat Kec. Medan Maimun mengatakan: "Saya sudah malas melihat calon yang ditawarkan, karena semua calon yang ditawarkan tidak cukup baik untuk menyelesaikan masalah di Kota Medan, dilihat dari track record calon tidak memiliki prestasi. Sehingga tidak ada pemberdayaan, pembangunan yang menjanjikan untuk saya percaya terhadap calon".

Faktor rendahnya kepercayaan masyarakat terhadap pemerintah dan calon diakibatkan masyarakat masih trauma terhadap Kepala Daerah sebelumnya terjerat kasus korupsi dan tidak dapat memenuhi janji - janji politiknya. Sehingga mempengaruhi perilaku masyarakat Kec. Medan Maimun untuk tidak memilih pada Pilgub Sumut 2018 dan faktor tersebut menjadi penyebab utama rendahnya partisipasi di Kec. Medan Maimun.

Faktor sosial dan ekonomi sering sekali mempengaruhi partisipasi masyarakat pada Pilkada. Melihat perilaku masyarakat keturunan Tionghoa di Kec. Medan Maimun terkesan apatis, eksklusif dapat dijadikan salah satu faktor rendahnya partisipasi politik. Faktor tersebut berpengaruh karena populasi ketiga terbesar Kec. Medan Maimun beragama Budha sebanyak 10.267 jiwa yang mayoritas keturunan etnis Tionghoa. 
Masyarakat keturunan Tionghoa sangat sulit untuk diajak kegiatan sosialisasi pada Pilgub Sumut 2018. Pendapat serupa, pernyataan Bpk. Edy Suhartono sebagai Komisioner KPU Kota Medan mengatakan: "Etnis Tionghoa di Kec. Maimun cukup besar dan menjadi salah satu penyebab, dialog saya dengan PPK mengatakan ada kesulitan sosialisasi kepada etnis Tionghoa dan saya juga membuktikannya ke kawasan Maimun dalam sosialisasi di kantor Lurah".

Sejarah kelam yang dialami masyarakat etnis Tionghoa (1998) dan masih terjadinya diskriminasi memunculkan ketakutan masyarakat Tionghoa untuk berinteraksi kepada masyarakat lainnya. Sehingga perilaku tersebut belanjut pada rendahnya kesadaran untuk mengikuti kegiatan Pilgub Sumut 2018, asumsi tersebut dapat dibuktikan dengan pernyataan masyarakat keturunan Tionghoa Kec. Medan Maimun yaitu Bpk. Vincent mengatakan: "Selama ini etnis Tionghoa masih mengalami diskriminasi di Kota Medan dikarenakan sebagai etnis minoritas, Faktor tidak adanya perlakuan adil dan kurangnya keamanan di Kota Medan mempengaruhi etnis Tionghoa enggan menggunakan hak pilihnya dan melihat Kasus krisis monter 98 juga mempengaruhi masyarakat etnis Tionghoa enggan untuk berpartisipasi."

Masyarakat Etnis Tionghoa tidak menggunakan hak pilih dipengaruhi tidak merasakaan manfaat terhadap kegiatan Pilkada. Hal senada dengan pernyataan Tokoh masyarakat Kec. Medan Maimun yaitu Bpk. Hadi Sumono yang mengatakan: "Mereka cenderung tidak menggunakan hak pilihnya saat Pilkada, alasan ini berdasarkan penglihatan saya di Kel. Suka Raja, Aur, Djati dan Hamdan, seperti sebelum hari pemilihan, sebagian besar mereka pergi liburan. Hal ini menjadi salah satu faktor yang mempengaruhi rendahnya partisipasi masyarakat Kec. Medan Maimun".
Selanjutnya, faktor tingkat pekerjaan masyarakat Kec. Medan Maimun mempengaruhi partisipasi pada Pilgub Sumut 2018. Berdasarkan persentase mata pencaharian menunjukkan mayoritas masyarakat bekerja sebagai Wiraswasta $30 \%$, Pedagang 24\%, dan Pegawai Swasta $16 \%$. Masyarakat yang didominasi pekerjaan tersebut, menjadikan memilih sebagai pilihan kedua dan fokus dalam memenuhi kebutuhan ekonominya. Pendapat ini dibuktikan dengan pandangan tokoh masyarakat Kec. Medan Maimun yaitu Bpk. Alimin mengatakan: "Mayoritas masyarakat Maimun berkerja di bidang barang dan jasa. Walau pihak pemerintah dan perusahaan sudah meliburkan saat pemilihan, masyarakat masih enggan menggunakan hak pilihnya. Masalah ini bisa dikarenakan sosialisasi yang tidak efektif, para KPPS dalam memberikan undangan ataupun sosialisasi melakukan pada saat jam kerja, maka sulit masyarakat mengikuti sosialisasi yang diberikan KPU".

Status sosial dan status ekonomi masyarakat Kec. Medan Maimun menjadi salah satu faktor penyebab rendahnya partisipasi pada Pilgub Sumut 2018. Status sosial dan ekonomi menengah keatas seperti keturunan Tionghoa, pekerjaan dan Pendapatan, tidak menggunakan hak pilihnya dipengaruhi tidak terpanggilnya emosi dan moral untuk memberikan suara. Meski tingkat pendidikan yang tinggi masih memiliki kesadaran dalam menggunakan hak pilih karena memiliki pemahaman dan tanggung jawab moral kepada masyarakat. Tetapi, status sosial dan ekonomi menengah kebawah tidak memberikan suaranya dipengaruhi pekerjaan, pendapatan dan kurangnya kepercayaan terhadap pemerintah, sehingga pada saat pemilihan seseorang tidak menggunakan hak pilihnya pada Pilgub Sumut 2018.

Afiliasi politik orang tua dapat mempengaruhi partisipasi seseorang dalam menggunakan hak plilhnya pada 
Pilkada. Afiliasi politik orangtua memiliki pemahaman dan perhatian terhadap politik yang dipengaruhi kecintaan terhadap suatu aliran yang berbasis organisasi politik dan semu politik. Afiliasi politik orangtua dalam mempengaruhi lingkungan masyarakat untuk ikut berpartisipasi dikarenakan masih banyak masyarakat yang sulit untuk menentukan pilihannya terhadap calon kepala daerah. Sehingga berdasarkan pengalaman dalam menelaah calon, sering kali afiliasi politik orangtua memberikan masukkan terhadap masyarakat yang tidak memiliki orientasi dalam menggunakan hak pilihnya pada Pilkada. Pendapat ini dapat diperkuat pernyataan Bpk. Edy Suhartono sebagai komisioner Kpu Kota Medan mengatakan bahwa: "Patronase orangtua dapat mempengaruhi seseorang dalam mengunakan hak pilih dan biasanya dilakukan pada basis agama, adat dan keluarga yang akhirnya dilakukan secara kolektifitas".

Faktor afiliasi politik orangtua terhadap keterlibatan pada kegiatan politik, sangat berperan dalam meningkatkan partisipasi masyarakat Kec. Medan Maimun pada Pilgub Sumut 2018. Afiliasi politik orangtua dalam penilaian masyarakat memiliki kepribadian ideologis, religus dan konsisten, sehingga pemilih pemula yang belum memiliki pengetahuan tentang pentingnya berpartisipasi dan masyarakat yang tidak memiliki oreintasi dalam memilih, sering menjadikan afiliasi politik orangtua sebagai rujukan dalam menentukan sikap, faktor tersebut mempengaruhi perilaku afilasi politik orangtua bertanggungjawab dalam mendorong masyarakat untuk menggunakan hak pilihnya pada Pilgub Sumut 2018.

Pengalaman

berorganisasi mempengaruhi seseorang untuk ikut berpartisipasi pada saat Pilgub Sumut 2018. Faktor tersebut dipengaruhi keterikatan organisasi seseorang yang memiliki peran terhadap pencapaian organisasi serta sikap tanggungjawab dalam situasi politik yang melibatkan dukungan. Seperti yang dikemukakan informan dari KPU Kota Medan yaitu Bpk Edi Suhartono sebagai Komisioner KPU Kota Medan mengatakan: "Pengalaman berorganisasi mempengaruhi seseorang untuk berpartisipasi, karena seseorang yang terlibat dalam organisasi politik dan sosial memiliki patron dalam kelompoknya yang sifatnya mempengaruhi".

Pengalaman berorganisasi seseorang dalam mempengaruhi masyarakat untuk berpartisipasi pada Pilgub Sumut 2018 dapat dibuktikan dengan pernyataan Bpk. Shah Alam selaku Ketua Hikma Kota Medan dan masyarakat Kec. Medan Maimun yang mengatakan: "HIKMA berupaya mempengaruhi masyarakat untuk berpartisipasi, dengan memberikan pemahaman kepada masyarakat dalam memilih pemimpin berdasarkan agamanya, penididikannya dan attitude".

Pengalaman berorganisasi mempengaruhi partisipasi masyarakat untuk ikut dalam kegiatan Pilgub Sumut 2018, faktor tersebut dipengaruhi pemahaman dan perhatian terhadap politik lebih baik yang cenderung berusaha memberikan kontribusi terhadap lingkungan masyarakat untuk berpartisipasi pada Pilgub Sumut 2018, pengalaman berorganisasi seseorang dalam kegiatan partisipasi politik berlaku pada organisasi politik dan semu politik.

\section{SIMPULAN}

Penelitian ini memberikan kesimpulan bahwa Hierarki partisipasi politik masyarakat Kec. Medan Maimun pada Pilgub Sumut 2018 lebih didominasi dalam partisipasi dalam pemberian suara dan apathi total. Faktor - faktor yang mempengaruhi rendahnya partisipasi politik masyarakat di Kec. Medan Maimun pada Pilgub Sumut 2018 yaitu: (1) Kesadaran politik masyarakat Kec. Medan Maimun dalam Pilkada hanya sebatas pemahaman saja tanpa dibarengi 
menggunakan hak pilih, (2) Rendahnya kepercayaan masyarakat terhadap pemerintah dan calon sangat mempengaruhi perilaku masyarakat Kec. Medan Maimun untuk tidak menggunakan hak pilihnya, (3) Status sosial dan Status ekonomi menengah keatas dan menengah kebawah tidak menggunakan hak pilih dipengaruhi mayoritas pekerjaan dibidang barang dan jasa. Selanjutnya, faktor yang mempengaruhi masyarakat berpartisipasi pada Pilgub Sumut 2018 yaitu: (1) afiliasi politik orangtua memiliki peran dalam mempengaruhi masyarakat untuk berpartisipasi, (2) Pengalaman Organisasi memiliki pemahaman dan perhatian terhadap politik lebih baik dan cenderung berusaha mempengaruhi masyarakat untuk berpartisipasi.

\section{DAFTAR PUSTAKA}

Hasibuan, S.J. Kadir, A. \& Nasution, M.H.T. (2018). Strategi Komisi Pemilihan Umum Provinsi Sumatera Utara Dalam Meningkatkan Partisipasi Masyarakat Pada Pemilihan Gubernur Sumatera Utara 2018. PERSPEKTIF, 7 (1): 1-5.

Hendrik, D. (2010). Variabel - Variabel Yang Mempengaruhi Rendahnya Partisipasi Politik Masyarakat Dalam Pilkada Walikota Dan Wakil Walikota Padang Tahun 2008. Jurnal Demokrasi. 11 (2): 137-148.

Ivanna, J. Pardede, A.J. \& Iqbal, M. (2018). Peran Media Cetak dalam Meningkatkan Partisipasi Politik Di Kelurahan Bandar Selamat Kecamatan Medan Tembung Kota Medan. Journal of Education, Humaniora and Social Sciences (JEHSS). 1 (1): 25-35.

Kusmanto, H., (2013). Peran Badan Permusyawaratan Daerah dalam Meningkatkan Partisipasi Politik Masyarakat, JPPUMA: Jurnal IImu Pemerintahan dan Sosial Politik UMA (Journal of Governance and Political UMA), 1 (1): 4147.

Miles \& Huberman. (2007). Analisis data Kualitatif. Jakarta: Penerbit Universitas Indonesia.
Pane, A.Y.P. (2015). Partisipasi Politik Masyarakat Dalam Pemilihan Kepala Daerah Provinsi Sumatera Utara Tahun 2013 Di Kota Padangsidimpuan. Tesis. Universitas Sumatera Utara.

Rush, M. \& Althoff, P. (2011). Pengantar Sosiologi Politik. Jakarta: Rajawali Pers.

Sholihin, R., Fitriyah, N., \& Sutadji, M. (2014). Partisipasi Politik Dalam Pemilihan Gubernur Provinsi Kalimantan Timur Periode Tahun 2013-2018 Di Kecamatan Sungai Pinang Kota Samarinda. Jurnal Administrative. 2 (4): 495505.

Simarmata, P.S. (2018). Partisipasi masyarakat Kota Medan Di Pilgubsu 58,38\%. Medanbisnisdaily. Medan 05 Juli. Hlm 1. Diakses dari

Siregar, G.F.B. (2019). KPU Medan Targetkan Partisipasi Pemilih Meningkat 60 Persen Di Pemilu 2019. Medan.Tribunnews. Medan 01 Januari. Hlm 1. Di akses dari

Suhartini, S. (2018). Analisis Partisipasi Politik Masyarakat Pada Pilkada Langsung Di Kabupaten Barito Selatan Tahun 2017. Tesis. Universitas Diponegoro.

Suharyanto, A., (2014). Partisipasi Politik Masyarakat Tionghoa dalam Pemilihan Kepala Daerah, JPPUMA: Jurnal IImu Pemerintahan dan Sosial Politik UMA (Journal of Governance and Political UMA), 2 (2): 166175

Suharyanto, A., (2016), Surat Kabar Sebagai Salah Satu Media Penyampaian Informasi Politik pada Partisipasi Politik Masyarakat, Jurnal Administrasi Publik: Public Administration Journal, 6 (2): 123-136.

Surbakti, R. (2010). Memahami Ilmu Politik. Jakarta: PT Grasindo.

Tarigan, M. (2009). Partisipasi Politik Masyarakat Kabupaten Temanggung Dalam Pelaksanaan Pilkada Tahun 2008. Tesis. Universitas Diponegoro.

Usfinit, Y., Suparjo, A., \& Setyawan, D. (2014). Perspektif Partisipasi Politik Masyarakat Pada Pemilihan Kepala Daerah Kota Malang. Jurnal Ilmu Sosial dan Ilmu Politik. 3 (1): 38-45.

Nawawi, H. (2019). Metode Penelitian Bidang Sosial. Yogyakarta: Gadjah Mada University Press.

Zega, M.A. Muda, I. Batubara, B.M. \& Suharyanto, A. (2018). Pengaruh Program Rumah Pintar Pemilu Terhadap Partisipasi Politik Masyarakat Pada Kantor Komisi Pemilihan Umum Kota Medan, PERSPEKTIF, 7 (2): 6065. 